Andrej Saje

\title{
Sklepanje krščanskega zakona na Zahodu in Vzho- du od pozne antike do zgodnjega srednjega veka
} Celebration of Christian Marriage in the West and East from the Late Roman to the Early Medieval Period

Povz̨etek: Razprava se osredotoča na razvoj krščanskih poročnih praks od tretjega stoletja do začetka drugega tisočletja, ko se na Zahodu glede na Vzhod na tem področju utrdi drugačna praksa. Kristjani prvih stoletij so se poročali v skladu z domačimi običaji. Ob koncu antike se začne v vzhodni Cerkvi pod vplivom semitskih kultur močneje poudarjati sakralni značaj zakona. Posledično pomen pridobiva liturgični poročni obred v Cerkvi z blagoslovom duhovnika, kar sčasoma postane redna praksa, potrjena tudi s cesarskimi odloki. Za razliko od bizantinske tradicije se na Zahodu pod vplivom rimskega prava kot bistveni tvorni element sklenitve zakona izrazito poudarja privolitev zaročencev, duhovniški blagoslov novoporočencev pa se zaradi pastoralnih razlogov samo priporoča in ostane fakultativen. Cerkev je zaročence zgolj spodbujala, naj se zaradi velikega pomena družine poročajo z javnim obredom pred Cerkvijo. Skupna točka obeh tradicij je v učenju, da zakon nastane s privolitvijo zaročencev, razlika pa je v vrednotenju duhovniškega blagoslova in vprašanja, ali je duhovnik za sklenitev poroke bistven. Na Vzhodu je cerkveni obred poroke obvezen od enajstega stoletja dalje, na Zahodu pa enotno cerkveno obliko poroke dobimo šele v šestnajstem stoletju.

Ključne besede: krščanski zakon, cerkveni očetje, vpliv tradicije, poročni obred, bizantinska tradicija, Zahodna Cerkev, cesarska zakonodaja

Abstract: The study focuses on the development of Christian wedding practices from the third century up to the beginning of the second millennium, when the West and the East settle on different practices. Christians in the early centuries celebrate marriage according to their local customs. At the end of the Roman period the Eastern Church, influenced by semitic cultures, begins to stress more strongly the sacred character of marriage. As a result, the liturgical rite for the celebration of marriage in the church, comprising the blessing of the newlyweds by a priest, gains importance; this eventually becomes standard practice con- 
firmed by imperial decrees. In contrast with the Bizantine tradition, the Western Church, influenced by the Roman law, stresses that matrimonial consent of the fiancés is the essential constitutive element of marriage contract, whereas the blessing of the newlyweds by a priest is recommended only for pastoral reasons and remains optional. Due to the great importance of family, the Church has encouraged fiancés to celebrate marriage through a public rite before the ecclesial assembly. Both traditions share the teaching that marriage is contracted through matrimonial consent of the fiancés; they differ in the valuation of the priestly blessing and whether a priest plays an essential role in the celebration of marriage. In the Eastern Church the ecclesial rite of celebration of marriage is mandatory from the eleventh century onward, while the Western Church gets a unified ecclesial form of celebration of marriage only in the sixteenth century.

Keywords: Christian marriage, Church fathers, influence of tradition, wedding rite, bizantine tradition, Western Church, imperial legislation

\section{Uvod}

Človek je ustvarjen kot svobodno in razumno bitje, kar mu v življenju omogoča možnost izbire. To dejstvo je še posebej pomembno, ko gre za temeljne življenjske odločitve, kot to nedvomno velja pri odločitvi za življenjski stan. Sklepanje zakonske zveze je pravica, ki izhaja iz človekove narave. Človeški osebi je dana ob spočetju, povezana pa je z njenim dostojanstvom. "Pri opredelitvi človekovega dostojanstva, " poudarja Globokar, »igrajo pomembno vlogo religiozne in filozofske podlage posameznega prepričanja $(2016,316)$. Pravica sleherne človeške osebe do ustanovitve družine je v skladu s splošno sprejetimi civilizacijskimi standardi tako temeljna, da je ne more nihče nikomur odreči. Institut zakonske zveze zaradi njenega velikega pomena za družbo in Cerkev presega izključno osebne interese zaročencev, zato ga že od starih kultur dalje družba in religija tudi ustrezno regulirata. (Slatinek 2017, 132; Valentan 2016, 608).

Današnje pojmovanje krščanskega zakona kot dosmrtne skupnosti med možem in ženo, ki je po svoji naravi naravnana $v$ blagor zakoncev in roditev ter vzgojo otrok, in ima med krščenimi po Gospodovi volji značaj zakramenta (ZCP, kan. 1055), lahko razumemo samo s poznavanjem svetopisemskih temeljev zakona in družine ter ob upoštevanju judovske, grške in rimske kulture (Saje 2003, 9-19; 2018, 815819), v katerih so prve krščanske skupnosti nastale. Poleg tega je treba upoštevati tudi tradicijo in nauk cerkvenega učiteljstva, ki ga predstavlja vsakokratni škofovski zbor v edinosti s papežem kot Kristusovim namestnikom na zemlji. Krščanstvo je ob svojem rojstvu in ob širjenju v nove dežele glede poročne prakse sprejemalo običaje posameznih kultur in na začetku posebnih poročnih obredov ni uvajalo. Cerkev je svetopisemske norme za krščanski zakon povzemala in kristjane spodbujala, naj se vzdržijo poganskih običajev - in zato za blagoslov novoporo- 
čencev prosijo škofa, kar pa se za veljavnost poroke ni zahtevalo. Na podlagi teoloških traktatov in pod vplivom rimskega prava se je oblikoval nauk, da zakon nastane s privolitvijo zaročencev (Robleda 1977, 179). ${ }^{1}$ Pod vplivom semitskih tradicij je pri veljavnosti zakona imela pomen tudi izvršitev zakona z zakonskim dejanjem. Način poročanja v prvih stoletjih po Kr. v različnih okoljih ni bil enak -ponekod so zakon sklepali v več stopnjah (kar je bilo značilno za semitske kulture), drugod, kot npr. v okoljih pod rimskim pravom, pa z enim samim obredom (Gaudemet 1989, 20).

S širjenjem krščanstva začne zakonska zveza značaj zasebnosti vse bolj izgubljati, od začetka srednjega veka pa dobiva vse večjo vlogo tudi javni poročni obred pred duhovnikom, ki vključuje tako liturgični ritual kot tudi blagoslov novoporočencev. Prva vidnejša teološka dela, ki obravnavajo krščanski zakon, izhajajo iz drugega stoletja, od četrtega stoletja dalje pa je krščanski zakon glede moralnih vidikov že redna tema posameznih koncilov, ${ }^{2}$ medtem ko glede predpisane oblike poroke takrat konkretnejših določb še ne najdemo. Ob obravnavi razvoja poročnih praks bomo izpostavili posebnosti zahodne in vzhodne krščanske tradicije, kjer se med njima kažejo prve razlike od začetka četrtega stoletja dalje. Za razliko od zahodne krščanske prakse, ki pod vplivom rimskega prava vidi tvorni vzrok zakona v privolitvi zaročencev $v$ zakon, vzhodno krščanstvo poudarja duhovno razsežnost in blagoslov, ki s stoletji pridobiva vse večji pomen. $V$ prispevku bomo na podlagi virov in literature opisali pomembnejše zgodovinske prelomnice in teološke tokove, ki so pojmovanje krščanskega zakona in poročnih običajev zaznamovali, tudi ob upoštevanju prvih pomembnejših civilnih predpisov za to področje.

\section{Poročna praksa in razvoj nauka zahodne Cerkve od tretjega do enajstega stoletja}

Praksa blagoslavljanja novoporočencev domnevno izhaja iz apostolskih časov, vendar pa do tretjega stoletja - razen pisma sv. Ignacija Antiohijskega ${ }^{3}$ (35-107) Polikarpu (69-155), škofu v Smirni - o tem nimamo zanesljivih virov. V antiki dokazov o blagoslavljanju zaročencev ne najdemo, zagotovo pa so prvi kristjani sklepali zakon pod vplivom poganskih običajev (Schillebeeckx 1963, 226). Šele od začetka četrtega stoletja dalje obstajajo prvi zanesljivi viri o molitvah in blagoslovu, s katerimi je škof (ali nižji duhovnik) novoporočenca pospremil v zakonski stan, pri

1 Po mnenju Roblede sta bila v rimskem pravu, ki je na koncept zakona v zahodnem krščanstvu odločujoče vplivalo, za zakonsko zvezo potrebna dva elementa - najprej privolitev in nato volja za vztrajanje v njem: prvi element za začetek zakona in drugi za njegovo uresničitev $(1977,179)$.

2 Prvi pomembnejši koncili v Elviri (okrog leta 300), Anciri (314) in Neocezareji (314-325) so glede krščanskega zakona obravnavali njegovo zakramentalno razsežnost, neločljivost in moralno plat zakonskega življenja, sam način poročanja pa ni bil vprašanje, ki bi zahtevalo posebno obravnavo (Godefroy, s.v. Le Mariage au temps des Pères).

3 „Conviene agli sposi e alle spose di stringere l'unione con il consenso del vescovo, perché le loro nozze avvengano secondo il Signore e non secondo la concupiscenza. Ogni cosa si faccia per l'onore di Dio." (Lettera a Policarpo, V.) 
čemer je treba izpostaviti, da blagoslov ne prinaša pravnih posledic, temveč je (bil) zgolj pastoralne narave. Zaradi poudarjanja svetosti zakona kot zaveze med Bogom in zakoncema same po sebi je Cerkev blagoslov novoporočencev zgolj priporočala (Ritzer 1962, 55-56; Visentin 1978, 32-48). Prva zanesljiva vira o poročnem obredu, ki je vseboval tudi blagoslov novoporočencev, sta sv. Ambrož (+ 397) in papež Siricij (384-399). Sv. Ambrož v pismu Vigilu, škofu v Tridentu, piše, da naj sklepanje mešanega zakona spremlja polaganje tančice in duhovniški blagoslov, ki je zaradi narave zakona kot božje-pravnega instituta za krščanstvo specifičen dejavnik (Ambrož 1988, 148-149). Tudi papež Siricij v pismu Imeriju, škofu v Taragoni, poudarja, da naj duhovnik pri poročnem obredu novoporočenca blagoslovi. Izpostavlja, da se blagoslov v primeru razveze in ponovne poroke ne more ponoviti, kar kaže na naravo zakona kot nerazvezne enote (Siricij 385, 1136-1137). Papež Inocenc I. (401-417) poudarja, da je duhovniški blagoslov novoporočencev v skladu z Božjim zakonom od vsega začetka $(404 ; 475)$.

Omenjeni viri nakazujejo, da je bil blagoslov novoporočencev vse pogostejši in priporočljiv, vendar pa ostaja bistveni element sklenitve zakona privolitev zaročencev, ki je bila praviloma izrečena v krogu domače družine. Cerkev je priznavala vsako obliko zakona, če je bil ta le sklenjen v skladu z običaji določenega kraja. $S$ priporočanjem duhovniškega blagoslova je želela poudariti velik pomen zakona in mu zagotoviti javni značaj. Da slednji ni bil obvezen, je po mnenju nekaterih pogojeno s takratno družbeno ureditvijo (Joyce 1955, 184). To je razvidno iz odloka cesarjev Teodozija II. in Valentinjana III., ki sta leta 428 objavila zakon, da odsotnost zunanjih poročnih formalnosti še ne pomeni nujno tudi neveljavne sklenitve zakona. ${ }^{4}$ Od četrtega stoletja dalje pa je Cerkev začela postopoma razvijati lastno poročno liturgijo, ki je bila, čeprav neobvezno, vse bolj v rabi. V Rimu in v Milanu najdemo $v$ tem času zametke poročne liturgije, imenovane velatio nuptialis, $v$ Španiji in Galiji pa se obred imenuje benedictio in thalamo (Ritzer 1962, 68-69;157-160; 203-205).

Pri rimskem obredu, o katerem prvi piše sv. Pavlin iz Nole (354-431), je prvič omenjeno, da je poročni obred z blagoslovom novoporočencev, med katerim duhovnik na glavo neveste položi pajčolan, vključen v evharistično daritev, ki je v Cerkvi $(1999,244)$. Velja poudariti, da ob tem ostajajo v veljavi tudi morebitne ostale poroke $v$ domačem okolju brez navzočnosti služabnika Cerkve. Sočasno z uveljavitvijo rimskega poročnega obreda se v Galiji v petem stoletju uveljavi drugačna praksa. Poročni obred se ne izvaja v cerkvi, temveč sta škof ali duhovnik povabljena na dom novoporočencev, kjer po izmenjavi privolitve blagoslov poteka v poročni sobi. Praksa se je iz Galije prenesla tudi v Španijo (Ritzer 1962, 38).

Nov način poročanja se uveljavi v germanskem svetu, kjer je poroka potekala v dveh delih. Konstitutivni element zakona je bila zaroka, ki je ob izmenjavi privolitve veljala kot civilno veljavna pogodba (Vertrag), ne samo med zaročencema, temveč

"Si donationum ante nuptias vel dotis instrumenta defuerint, pompa etiam aliaque nuptiarum celebritas omittatur, nullus aestimet, ob id deesse recte alias inito matrimonio firmitatem, vel ex eo natis liberis iura posse legitimorum auferri, si inter pares honestate personas, nulla lege impediente, fiat consortium, quod ipsorum consensu atque amicorum fide firmatur.« (Cod. Theod., 3.7.3) 
tudi med njunima družinama. Liturgični obred z blagoslovom novoporočencev, ki ga opravi duhovnik, je bil omejen strogo na cerkev in ni imel nikakršnih pravnih učinkov (Friedberg 1965, 24). Ob koncu prvega tisočletja je Cerkev vedno močneje vztrajala, naj bo poročni obred pred Cerkvijo (in facie Ecclesiae), da bi tako zakonski zvezi zagotovili javni značaj in preprečili sklepanje zakonov v tajnosti, kar je zaradi pomanjkanja pravne jasnosti in posledičnih zlorab povzročalo vedno večje težave (Nocent 1986, 347). Sočasno postaja vse pomembnejši tudi duhovniški blagoslov novoporočencev, ki je razumljen predvsem kot potrditev legitimnosti sklenjenega zakona in njegova posvetitev. Pri tem konstitutivni trenutek sklenitve zakona vendarle ostaja izmenjava privolitve, blagoslov pa ohranja fakultativni značaj.

Izjemno dragocen dokument za razumevanje izmenjave privolitve $v$ zakon in duhovniškega blagoslova predstavlja pismo papeža Nikolaja I. (858-867) bolgarskemu vladarju. Povod za njegovo pisanje je bil v učenju nekaterih grških duhovnikov, da je duhovniški blagoslov za veljaven zakon bistven in nujen. Papež v pismu izpostavlja, ${ }^{5}$ da je takšno učenje v neskladju z resnico in da je edini konstitutivni element sklenitve poroke privolitev zaročencev (Nikolaj I. 866, 643; Weber 2001, 31-40). Na podlagi tega vira lahko papežev poudarek razumemo, da privolitve v zakon kot bistvenega in tvornega elementa ne moreta nadomestiti ne blagoslov ne kakšen drug ritual. Vrhovni poglavar Cerkve spodbuja, naj se zakon zaradi njegovega javnega značaja in jasnosti, kdo je poročen, sklepa, če je le mogoče, v cerkvi, vendar pa cerkvenega obreda za veljavnost ne predpisuje. Iz konteksta je razvidno, da se je na Vzhodu za razliko od latinske Cerkve že uveljavila poročna praksa s kronanjem neveste in obveznim duhovniškim blagoslovom novoporočencev. Ta praksa dobi pravno obliko in postane obvezna z odlokom (Nov. 89) cesarja Leona VI. „Modrega« (886-912), da je kronanje neveste in blagoslov novoporočencev bistveni sestavni del poroke za veljavnost tudi v civilnem smislu (Berger 2006, 87), kar je imelo po mnenju Popova za sklepanje zakona v prihodnje odločujoč pomen. ${ }^{6}$

Na podlagi omenjenih virov lahko pridemo do sklepa, da je imela zakonska zveza v latinski Cerkvi v prvem tisočletju predvsem sekularni značaj - cerkveni poročni obred se je priporočal predvsem zaradi moralnih in pastoralnih razlogov. Cerkev glede poročanja ni imela enotne prakse, pa tudi ne enotnih pravnih in liturgičnih predpisov. Avtorji se strinjajo glede dejstva privolitve zaročencev kot tvornega dejavnika sklenitve zakonske zveze. Poroko sta sklenila zaročenca sama, prisotnost duhovnika je bila vse bolj zaželena, vendar fakultativna. Cerkev je še zlasti od desetega stoletja dalje vedno močneje priporočala, naj si zaročenca izmenjata pri-

„Secondo le leggi sia sufficiente solo il consenso di coloro della cui unione si tratta; se esso unico dovesse essere mancato alle nozze, tutto il resto, anche se celebrato con lo stesso coito, è inutile, come testimonia il grande dottore Crisostomo che dice: Non il coito fa il matrimonio, ma la volontà."

6 Popov pomen nove uredbe izpostavlja takole: "Sempre dall'imperatore Leone venne emanata in materia una disposizione chiara e completa. Prima, asseriva nella sua novella, si faceva tutto senza benedizione perché si pensava che, così facendo, non avrebbero offeso nessuno, non essendoci specifiche esigenze religiose o morali: senza benedizione si facevano le adozioni, senza benedizione iniziavano la vita matrimoniale. Ma noi, poiché tutto per grazia di Dio va stabilito con decoro, non conviene seguire l'antichità; pertanto, dichiarava Leone, noi ordiniamo che sia le adozioni che i matrimoni ricevano conferma dalla benedizione ecclesiastica e dove non c'è questo mezzo che rinsalda, il coniugio non ha inizio effettivo e la coabitazione non sarà legittima.« $(2017,221)$ 
volitev javno pred Cerkvijo, duhovnik pa je pri tem že tudi imel nalogo, da pri zaročencih preveri, ali morda obstaja kakšen zakonski zadržek oz. ali zakonu med njima kaj nasprotuje (Le Bras, s.v. «La doctrine du mariage»; Gismondi 1949, 314).

\section{Poročna praksa v bizantinski tradiciji}

Omenili smo že, da do začetka tretjega stoletja glede poročnih praks na Vzhodu in Zahodu ni bilo bistvenih razlik. Kristjani so se poročali v skladu s prakso kraja bivanja, zakonska zveza pa je imela v vseh kulturah velik pomen, ki je presegal zgolj voljo zaročencev. Iz Sirske didaskalie, enega izmed najstarejših ohranjenih krščanskih virov, glede porok izhaja, da je bila za starše pravočasna poroka njihovih otrok posebna skrb. Poroka je bila zato stvar tako domače družine kot tudi širše civilne skupnosti, glavno vlogo pri sklenitvi pa je imel nevestin oče (Achelis, in Flemming 1904, 115). Škof (ali nižji duhovnik) sta novoporočenca za to priložnost obiskala na domu, kjer sta opravila liturgične obrede s pesmimi in himnami ter ju blagoslovila (Prader 1992, 196).

V četrtem stoletju na Vzhodu opazimo prvi večji premik. Cerkev začne sklepanje krščanskih porok spremljati skrbneje, še posebej, kadar je šlo za drugo sklenitev zakona ali pa $\mathrm{v}$ primeru poroke med kristjanom in poganko ali obratno (Zhishman $1864,670)$. Vzhodna teologija in poročno liturgično obredje sta bila za razliko od zahodne Cerkve, kjer je bil poudarjen pravni značaj zakona, močno zaznamovana s Pavlovim pojmovanjem krščanskega zakona kot zveze med Kristusom in Cerkvijo (Ef 5, 22-33). Vzrok za poudarjanje duhovnega značaja zakonske zveze raziskovalci vidijo tudi v vplivu semitskih kultur, ki so že pred nastankom krščanstva zakonsko zvezo videle kot nekaj svetega in presežnega (Prader 1992, 195-196; Ritzer $1962,52)$. V grško-bizantinski Cerkvi se postopoma uveljavi poročna praksa sklepanja zakona po stopnjah, kjer so obred zaroke začeli razlikovati od same poroke. Zaroka je bila lahko dveh vrst. Prva oblika je bila brez večjih zunanjih formalnosti, pri drugi obliki zaroke pa je morala nevesta dobiti dar (arrha), ki ji v primeru ločitve služil za preživetje. ${ }^{7}$ Druga oblika zaroke se je uveljavila še zlasti v Mali Aziji in je zaradi zaščite žene dobila pravni značaj. V prvih stoletjih razdrtje zaroke pravnih posledic ni imelo (Herman 1935, 81-82), pod vladavino cesarja Justinijana pa je bil dar nevesti v primeru razdrtja zaroke obravnavan kot osnova za njeno samostojno življenje. Če je ločitev sprožila nevesta, je morala dar vrniti v dvojni vrednosti. ${ }^{8} \mathrm{Na}$ Vzhodu zaroka torej postopoma pridobiva pravno in zavezujočo naravo,

Année naravo instituta arrha razlaga takole: „En Asie Mineure, il était d'usage, lors des fiançailles, que le jeune homme remît à sa fiancée, ou aux parents de celle-ci, une somme d'argent ou quelques objets de valeur. En cas de rupture de l'engagement, il perdait tout droit sur eux, mais si la rupture était le fait de la fiancée, ces objets lui étaient rendus à un multiple déterminé.« (1935, 528-529)

8 „Mulier iuris sui constituta arrarum sponsalium nomine usque ad duplum teneatur, id est in id quod accepit et aliud tantundem nec amplius, si post completum vicesimum quintum annum vel post impetratam veniam aetatis atque in competenti iudicio comprobatam huiusmodi arras suscepit: in simplum autem, id est tantummodo quod accepit, si minoris aetatis est, sive virgo sive vidua sit, sive per se sive per tutorem vel curatorem vel aliam personam easdem arras acceperit.« (Cod. lust., 5,1,5) 
takšno pojmovanje predzakonske obljube pa vpliva tudi na prakso Cerkve in njeno razumevanje zakonskega odnosa kot podobe zaveze med Kristusom in Cerkvijo. Razdrtje zaroke ni bilo dovoljeno in se je ob poskusu sklenitve zakona s tretjo osebo obravnavalo kot prešuštvo (Schillebeeckx 1963, 316). Poroke so se v bizantinskem delu sveta ob koncu četrtega stoletja praviloma obhajale v okviru domače družine. Obred je bil sestavljen iz izmenjave privolitve in blagoslova prstanov, samo občasno so bile vanj vključene tudi molitve, ki jih je opravil duhovnik. Kler navadno na porokah ni bil prisoten, njegova vloga je bila predvsem v nadzoru in preprečevanju poročnih nepravilnosti, ki bi nasprotovale krščanskemu pojmovanju zakona; posebej je bila odsvetovana poroka med kristjani in pogani (Dacquino $1984,197)$. Čeprav je na Vzhodu sakralni značaj zakonske zveze poudarjen od vsega začetka, so bile poroke že zelo zgodaj tudi stvar države in civilne ureditve. Cesarska oblast si je vzela pristojnost, da zaradi velikega pomena zakonske zveze za družbo, javno dobro in razjasnitve pravnega statusa oseb to področje pravno regulira. Cerkveni obred, ki mu predseduje duhovnik, postane v Cerkvi grško-bizantinskega obreda obvezen šele proti koncu prvega tisočletja. Od tega trenutka dalje je bistveni element poroke blagoslov novoporočencev, ki ga podeli duhovnik.

Med posebnostmi poročnega obreda na Vzhodu velja omeniti prakso kronanja neveste, ki so jo imenovali tudi stephanôma. Po mnenju nekaterih avtorjev je obred poganskega izvora, v vzhodni Cerkvi pa se je uveljavil pod vplivom sv. Janeza Krizostoma in v poznejšem času postal tipični sestavni del poročnega obreda (Dauvillier, in De Clercq 1936, 40; Ritzer 1962, 73; Schillebeeckx 1963, 317). V času antike je vloga kronanja neveste pripadala njenemu očetu, pozneje pa se obred zaradi poudarjene svetosti zakona prenese na duhovnika ali škofa. To prakso potrjuje pismo Gregorja Nazianškega (280-374) prijatelju Evzebiju, v katerem se mu opravičuje zaradi odsotnosti na poroki njegove hčerke - zaradi bolezni se sklenitve njenega zakona ni mogel udeležiti in posledično tudi ne podeliti blagoslova, kakor si je sama želela. Prijatelja tako prosi, naj blagoslov podeli hčerki kar sam. ${ }^{9}$

Običaj kronanja neveste se v četrtem stoletju uveljavi med armenskimi kristjani, kjer je par po kronanju prejel tudi evharistijo. Ta navada se je domnevno zopet pod vplivom sv. Janeza Krizostoma prenesla tudi v grško Cerkev, kjer se začne uveljavljati proti koncu šestega stoletja (Herman 1938, 196). Obred postopoma postane redna cerkvena praksa tudi drugod na Vzhodu. Duhovnikovo kronanje novoporočencev so razumeli kot čast - kot da je Kristus sam, ki ju krona in jima po obredu duhovnika podeli svoj blagoslov (Janez Krizostom, Hom. 9, 546). Cerkev je sicer v primeru ločitve zakoncev in njihove morebitne ponovne poroke takšen blagoslov strogo zavračala. ${ }^{10}$ Blagoslov je bil razumljen predvsem kot prošnja Bogu za novo družino.

V začetku srednjega veka je bila v bizantinskem okolju izmenjava privolitve $v$

9 „Caetera autem vobis curae sint, ac pater filiam vittis redimiat ut optavit. Hoc enim, et sicuti nuptiis interfuimus, praescripsimus; nempe ipsorum coronas esse, nostrum autem esse preces, quas scio locis minime definitas ac circumscriptas. " (Epistola 231, in PG 37, 374)

10 Prepoved blagoslova zaročencev ob morebitni drugi poroki je razvidna iz predpisov Niceforja (806-815), patriarha v Konstantinoplu, ki je zapisal: »Bigamus non coronatur« $(1868,328)$. 
zakon njegov del, ki je bil izveden v trenutku zaroke (Prader 1992, 33), od osmega stoletja dalje pa postane del obreda $v$ cerkvi, kjer sprejme privolitev duhovnik kot uradna priča Cerkve. Schillebeeckx posebej poudarja, da je enako kot v zahodni Cerkvi tudi na Vzhodu privolitev bistveni tvorni element sklenitve zakona, blagoslov pa je dodan kot priprošnja Bogu. To se razume tudi iz dejstva, da je obred dolgo časa potekal v okviru domačega okolja in za veljavnost zakona ni bilo pomembno, ali je blagoslov podelil oče ali duhovnik $(1963,318)$. Zhishman poudarja, da sta služabnika poroke na Vzhodu in Zahodu zaročenca sama, duhovnik pa dobi vlogo uradne priče Cerkve, torej v njenem imenu sprejme privolitev. ${ }^{11}$ Obredu kronanja je sledila izročitev neveste ženinu (traditio sponsae). Oče je hčer izročil možu, in s tem je prišla pod njegovo oblast. Ker sta obreda potekala v sosledju, sčasoma postaneta pristojnost duhovnika. Iz tega običaja se poroka na Vzhodu razvije v pravi liturgični obred, kjer duhovnik dobi prevladujočo vlogo, čeprav ne povsod v vzhodni Cerkvi na enak način (Zhishman 1864, 156-160). Duhovniški blagoslov kot bistveni sestavni del sklenitve zakona je bil prvič opredeljen v armenski Cerkvi, kar je razvidno iz njene zbirke apostolskih kanonov, ki so bili leta 365 vključeni v dokumente koncila $v$ Ashirsmatu. ${ }^{12} \mathrm{~V}$ sirski Cerkvi je bil blagoslov za veljavnost zakona predpisan v osmem stoletju (Prader 1992, 198), podobno se začne poroka obhajati tudi v aleksandrijski Cerkvi, kjer izmenjava privolitve zaročencev poteka med evharistično daritvijo (Dauvillier in De Clercq 1936, 70).

\subsection{Poročne uredbe civilne oblasti}

Na podlagi primerjave ugotavljamo, da je Cerkev na Vzhodu od četrtega stoletja vernike sicer spodbujala, naj poroka poteka javno pred Cerkvijo oz. v navzočnosti duhovnika, vendar pa med posameznimi deli vzhodne Cerkve obstajajo razlike. Ponekod so zakonsko zvezo lahko sklepali zgolj v domačem okolju v navzočnosti nevestinega očeta brez duhovnika do vključno osmega stoletja. Do tega časa so imeli npr. v bizantinski Cerkvi zaročenci možnost sklenitve poroke $v$ tudi le pisni obliki (Zhishman 1864, 158). Duhovniški blagoslov je dobil značaj nujnosti v devetem stoletju z odlokom Niceforja (806-815), patriarha v Konstantinoplu, po katerem brez blagoslova ni bilo zakona niti za sužnje. ${ }^{13}$

$\checkmark$ razpravi smo že omenili, da je zakonsko zvezo na Vzhodu že zelo zgodaj urejala tudi cesarska oblast. Glede na tesno povezanost civilne in cerkvene oblasti je obveljala praksa, da so krščansko veljavni zakoni veljavni tudi pred civilno oblastjo, s tem da je začela civilna oblast predpisovati potrebne formalnosti za poroko tudi

11 Avtor izpostavlja: „Dass der Spender des Ehesakramentes niemand anderer sein kann, als die künftigen Ehegatten in ihrer wechselseitigen Beziehung, ergibt sich abgesehen von dem bisher gesagten aus der bei der Einsegnung des Verlöbnisses angewendeten kirchlichen Formel, welche ähnlich mit der bei der später folgenden Krönung lautet: Es wird verlobt (gekrönt) der Diener (die Magd) Gottes im Namen des Vaters, des Sohnes und des heiligen Geistes. « $(1864,135)$

12 Koncil v kan. 33 predpisuje: »Per dexteram sacerdotis mano eiusque benedictionem homo in matrimonium coniungitur." (Fonti CICO, ser. II, fasc. XXI, 27)

13 Na vprašanje, ali se je sužnjem dovoljeno poročiti brez duhovniškega blagoslova, patriarh odgovarja takole: "Coniunctio sine sacerdotali benedictione est fornicatio, sive servus, sive liber sit. " (Nicefor 1868, 346) 
sama. Cesar Justinijan (527-565) je tako leta 537 določil, da se mora višji sloj prebivalstva poročiti v navzočnosti služabnika Cerkve, poroko pa je treba zapisati v arhive. Namen te uredbe je bil zagotoviti zakonitost otrok. Nižji sloj je lahko sklepal zakon brez teh formalnosti zgolj z izmenjavo privolitve (Nov. 74, 4). V tem času sta sicer v bizantinskem cesarstvu veljali dve obliki poroke; prva, bolj razširjena oblika je bila z zaroko in izmenjavo darov (arrha), kar je moralo biti potrjeno s pisnim dokumentom - ta oblika je bila določena že z zakonodajo cesarja Teodozija (Cod. Theod., 3.5.2). Druga oblika je bila sklenitev zakona s privolitvijo zaročencev (Schillebeeckx 1963, 320). Naslednjo pomembno uredbo je nato izdal cesar Leon III. (717-741), ki je za veljavnost poroke določil pisno pogodbo glede dote, kjer sta morali biti navzoči zanesljivi priči. Če to zaradi revščine posameznih oseb ni bilo izvedljivo, je zadostovala izmenjava privolitve v navzočnosti staršev, pospremljena z liturgijo v cerkvi.

Po zgledu Cerkve je v devetem stoletju javno obliko poroke začela spodbujati tudi civilna oblast. Vladar Basilij I. Makedonski (867-886) je za civilno veljavnost zakona določil, da se naj ta sklene pred duhovnikom (Ritzer 1962, 113). Kljub tesni povezanosti države in Cerkve je med institucijama pri vrednotenju zaroke prihajalo do razhajanj. Bizantinska Cerkev je denimo s trulansko sinodo (691) v kan. 98 preklic zaroke in poroko s tretjo osebo obravnavala kot prešuštvo. Civilna oblast te odločitve ni sprejela, posledično je bila razdrta zaroka brez pravnih posledic dopustna, še posebej, kadar je šlo za mladoletne osebe (Zhishman 1864, 142-143). Kompromisno rešitev je našel cesar Leon VI. (886-912), filozof, ki je leta 895 predpisal minimalno starost za poroko: petnajst let za fante in trinajst za dekleta. $V$ skladu z njegovim odlokom je bila od tedaj dalje civilno veljavna vsaka oblika poroke $v$ navzočnosti duhovnika, ki je vključevala njegov blagoslov (Zepos in Zepos 1962, I, 156). Ta uredba je izenačila cerkveno obliko zaroke s civilno pogodbo. Zgolj civilna zaroka je bila razvezljiva, glede na pojmovanje nerazveznosti cerkvene zaroke pa tega značaja ni imela zaroka, sklenjena z verskim obredom. S takšno razlago se ni strinjala bizantinska Cerkev, ki je kot nerazvezno pojmovala tudi civilno zaroko, sklenjeno z darom (arrha), čeprav v odsotnosti duhovnika (Ritzer 1962, 119). Nejasnosti je naredil konec cesar Aleksij Komnen (1081-1118) z Bulo aureo leta 1084, v kateri je določil, da je slovesna zaroka, ki se obhaja v cerkvi, hkrati tudi veljavna civilna poročna pogodba. Od tega trenutka dalje civilna zaroka z izmenjavo darov ni več imela pravnega učinka in je bila odpravljena. V grško-bizantinski Cerkvi se tako za versko in hkrati civilno področje uveljavi enoten poročni obred v cerkvi. Sestavljen je iz dveh delov, zaroke in same poroke. Duhovniški blagoslov postane obvezen sestavni del poročnega obreda, brez katerega poroka ni veljavna ne pred Cerkvijo in ne pred državo. S tem se praksa poročanja v vzhodni Cerkvi dokončno loči od zahodne, kjer je privolitev zaročencev konstitutivni značaj sklenitve zakona ohranila. Cesarska zakonodaja je na Vzhodu obveljala tudi za cerkveno področje. Obred kronanja in duhovniški blagoslov je tako tam od enajstega stoletja bistveni sestavni del poročnega obreda, sužnji pa so enaki svobodnim (Zhishman 1864, 637-640). Duhovniku se pripiše vloga pristojnega poročevalca ali služabnika poroke, ki zaročencema podeli zakrament. Na Zahodu enotne oblike poroke ni bilo vse do tridentinskega koncila leta 
1563, ko je latinska Cerkev uzakonila poroko pred domačim župnikom in pričama, kar pa praviloma ni imelo tudi civilne veljave. Za razliko od vzhodne Cerkve se na Zahodu civilna oblast v cerkveno poroko ni vmešavala.

\section{Sklep}

Na podlagi analitične in zgodovinsko-pravne primerjalne študije vzhodne, bizantinske, in zahodne, rimske, tradicije poročnih praks ugotavljamo, da sta na Vzhodu Cerkev in država ves čas močno povezani. Glede na velik pomen družine za Cerkev in družbo se obe instituciji čutita pristojni in dolžni, da poročne formalnosti regulirata. Medtem ko vzhodna Cerkev z oblikovanjem poročne liturgije poudarja duhovne razsežnosti zakona in vlogo duhovnika kot uradnega predstavnika Cerkve, ki sklepa obred, se civilna oblast temu vprašanju posveča predvsem iz praktičnih razlogov, to je zaradi razjasnitve pravnega statusa oseb, $s$ katerim so povezane tudi določene odgovornosti, npr. v primeru ločitve zakoncev preživnina, skrb za otroke, dedovanje itd. Kljub različnosti njune narave in drugačnim interesnim področjem uspeta obe strani po večstoletnih prizadevanjih priti do medsebojnega soglasja in do enotnega poročnega obreda. Vladar potrjuje cerkvene zakone, slednji posledično veljajo tako za Cerkev kot za državo. Zahodna Cerkev ves čas ohranja raznovrstnost običajev in kljub pomanjkanju evidenc o statusu oseb in s tem povezanimi zlorabami obvezne oblike poroke ne predpisuje. Vernikom pušča svobodo, vedno bolj pa teži $k$ javni obliki poroke. $Z$ državo na tem področju ne sodeluje, cerkveni zakoni praviloma tudi nimajo civilnih učinkov. Liturgično obhajanje sklenitve zakona na Vzhodu se začne imenovati "sveti obred«. Vzrok za takšno razumevanje poročnega obreda izhaja iz prepričanja, da je tisti, ki po obredu duhovnika kot služabnika zakramenta združi zakonca, Bog. Posledično je vprašanje, kdo zakrament zakona podeljuje, na Vzhodu aktualno mnogo prej kot na Zahodu, kjer se je utrdil nauk, da si zakrament sv. zakona podelita zaročenca sama ob navzočnosti duhovnika - ki pa je za razliko od vzhodne prakse zgolj kvalificirana priča Cerkve in pri sklenitvi zakona nima bistvene vloge. Različna in močno zasidrana dvojna tradicija razumevanja istega krščanskega zakona, ki se kaže tudi v neenotni terminologiji glede konstitutivnih in bistvenih elementov sklenitve zakona, je imela vidne posledice za teološka razpravljanja o bizantinski in latinski tradiciji v naslednjih stoletjih, ko je Cerkev izoblikovala nauk o zakramentih in o tem, kdo jih lahko podeljuje.

\section{Kratice}

Bd. - Band.

Cod. lust. - Codex lustinianus [Justinijanov zakonik (tudi Justinijanov kodeks) je izraz za zbirko zakonov, ki jih je zbral bizantinski cesar Justinijan (527-567); veljati je pričel 16. aprila 529].

Cod. Theod.- Codex Theodosianus [Teodozijev zakonik je zbirka zakonov krščan- 
skih cesarjev Rimskega cesarstva; delovno skupino za zbiranje zakonov sta ustanovila cesar Teodozij II. in njegov socesar Valentinijan III., v veljavo je stopil 1. januarja 439].

CSEL - Corpus scriptorum ecclesiasticorum latinorum.

DS - Enchiridion symbolorum, definitionum et declarationum de rebus fidei et morum. Bologna: Edizioni Dehoniane, 1995.

DThC - Dictionnaire de Théologie Catholique. Zv. 9/2. Pariz: Letouzey \& Ané, 1927.

EJCan - Ephemerides luris Canonici.

Fonti CICO - Fonti Codificazione Canonica Orientale. Città del Vaticano: Tipografia poliglotta vaticana, 1930-1934 [Serie I., fasc. 1-12, 15]; 19351951 [Serie II., fasc. 1-30].

Hft. - Heft.

MANSI - J. D. Mansi, ur. Sacrorum Conciliorum nova et amplissima collectio, 1-30. Graz: Akademische Druck- u. Verlagsanstalt, 1960-1962.

Nov. - Novellae lustiniani [Zbirka zakonskih predpisov rimskega prava v latinskem in grškem jeziku, ki so nastale v času cesarja Justinijana po letu 535].

OChP - Orientalia Christiana Periodica.

PL - J.P. Migne, ur. Patrologiae cursus completus. Series Latina. Pariz: Apud Garnier, 1844-1864.

PG - J.P. Migne, ur. Patrologiae cursus completus. Series Graeca. Pariz: Apud Garnier, 1857-1866.

ZCP - Zakonik cerkvenega prava. 1983. Ljubljana: Nadškofijski ordinariat. ZSRG.K - Zeitschrift der Savigny-Stiftung für Rechtsgeschichte. Kanonistische Abteilung.

\section{Reference}

Achelis, Hans, in Johann Flemming. 1904. Die ältesten Quellen des orientalischen Kirchenrechts: Die Syrische Didascalia. V: Texte und Untersuchungen zur Geschichte der altchristlichen Literatur. Neue Folge. Zv. 10/2. Leipzig: Hinrichs.

Anné, Lucien. 1935. La conclusion du mariage dans la tradition et le droit de l'Église jusqu'au VI siècle. Ephemerides Theologicae Lovanienses 12:513-550.

Ambrož. 1988. Epistulae XXXVI-LXIX; Epistola 62. $\mathrm{V}$ : Tutte le opere di Sant'Ambrogio. Milano: Città nuova.

Berger, Albrecht. 2006. Life and works of Saint Gregentios, archbishop of Taphar. Berlin: Walter de Gruyter.

Codex Iustinianus. B.I. https://droitromain.univgrenoble-alpes.fr/Corpus/CJ5.htm\#1 (pridobljeno 11. 11. 2019)
Codex Theodosianus. B.I. http://ancientrome.ru/ ius/library/codex/theod/tituli.htm (pridobljeno 3. 11. 2019)

Dacquino, Pietro. 1984. Storia del matrimonio cristiano alla luce della Bibbia. Torino: Elledici.

Dauvillier, Jean, in Charles De Clercq. 1936. Le mariage en Droit Canonique Oriental. Pariz: Sirey.

Gaudemet, Jean. 1989. II matrimonio in Occidente. Torino: Società editrice internazionale.

Gismondi, Pietro. 1949. La celebrazione del matrimonio secondo la dottrina e la legislazione canonica sino al Concilio tridentino. EJCan 5:301-338.

Globokar, Roman. 2016. Etični razmislek o žrtvovanju človeških zarodkov $v$ znanstvene namene. Bogoslovni vestnik 76, št. 2:313-332.

Godefroy, Louis. 1927. Le mariage au temps des Pères. V: DThC 9/2, 2077-2123. 
Gregor Nazianški. B.I. Epistola 231. V: PG 37, 373-374.

Le Bras, Gabriel. 1927. La doctrine du mariage chez les théologiens et les canonistes depuis I'an mille. V: DThC 9/2, 2123-2317.

Friedberg, Emil. 1965. Das Recht der Eheschließung in seiner geschichtlichen Entwicklung. Aalen: Scientia.

Herman, Emil. 1935. Die Schliessung der Verlöbnisse im Recht Justinians und der späteren Byzantinischen Gesetzgebung. V: Miscellanea iuridica Iustiniani et Gregorii IX, 79-107. Roma: Typis Pont. Univ. Gregorianae.

- - . 1938. De benedictione nuptiali quid statuerit ius byzantinum sive ecclesiasticum sive civile. OChP 4:189-234.

Ignacij Antiohijski. B.I. Lettera a Policarpo. https:// www.vitanostra-nuovaciteaux.it/ignazio-di-antiochia-lettera-a-policarpo-testo/ (pridobljeno 5. 11. 2019).

Inocenc I. 404. Lett. Etsi tibi. 15. 2. V: PL 20, 468481.

Iustiniani Novellae. B.I. https://droitromain.univgrenoble-alpes.fr/Corpus/Novellae.htm (pridobljeno 4. 11. 2019).

Janez Krizostom. B.I. In epist. I ad Timotii, Hom. 9. V: PG 62, 543-548.

Joyce, George Hayward. 1955. Matrimonio cristiano. Alba: Edizioni Paoline.

Nicefor. 1868. Ex constitutionibus ecclesiasticis. V: Iuris ecclesiastici Graecorum historia et monumenta. Zv. 2, 314-350. Ur. I.B. Pitra. Rim: Typis Collegii Urbani.

Nikolaj I. 866. Risp. Ad consulta vestra. 13.11. V: DS, 643-648.

Nocent, Anscar. 1986. II matrimonio cristiano. V: La liturgia, i sacramenti: teologia e storia della celebrazione, 300-362. Anamnesis 3/1. Genova: Marietti.

Pavlin iz Nole. 1999. Carmen XXV. V: CSEL 30, 238-245. Dunaj: Österreichischen Akademie der Wissenschaften.

Popov, Nikolaj. 2017. Stato e Chiesa a Bisanzio al tempo dell'imperatore Leone VI il Saggio (886912). Ur. Nicola Cariello. Rim: Arbor Sapientiae.

Prader, Josef. 1992. I/ matrimonio in Oriente e Occidente. Rim: Pontificio Istituto Orientale.
Ritzer, Korbinian. 1962. Formen, Riten und religiöses Brauchtum der Eheschließung in den christlichen Kirchen des ersten Jahrtausends. Münster: Aschendorffsche Verlagsbuchhandlung.

Robleda, Olis. 1977. Intorno alla nozione di matrimonio nel diritto romano e nel diritto canonico. Apollinaris 50:172-193.

Saje, Andrej. 2003. La forma straordinaria e il ministro della celebrazione del matrimonio secondo il codice latino e orientale. Rim: Pontificia Università Gregoriana.

- - - 2018. Vpliv poročnih praks starih kultur na sklepanje zakona prvih kristjanov. Bogoslovni vestnik 78, št. 3:813-823.

Schillebeeckx, Edward. 1963. I/ matrimonio è un sacramento. Milano: Edizioni Paoline.

Siricij. 385. Lett. Ad decessorem ad Himerium episcopum Tarraconensem. 10. 2. V: PL 13, 1131-1147.

Slatinek, Stanislav. 2017. Pastoralni izzivi za uspešen pogovor $z$ duhovnikom in foro interno $v$ luči posinodalne apostolske spodbude Radost ljubezni - Amoris laetitia. Bogoslovni vestnik 77, št. 1:131-144.

Valentan, Sebastijan. 2016. Prenova kanonskega postopka v ničnostnih zakonskih pravdah in pojasnila Papeškega sveta za zakonska besedila. Bogoslovni vestnik 76: št. 3/4:607-619.

Visentin, Pelagio. 1978. II matrimonio nella luce della teologia patristica. V: I/ matrimonio cristiano: Studi biblici, teologici e pastorali, 32-48. Torino: Leumann.

Weber, Ines. 2001. Consensus facit nuptias! Überlegungen zum ehelichen Konsens in normativen Texten des Frühmittelalters. ZSRG.K 87:3166.

Zepos, Panagiōtēs, in lōnnes Zepos, ur. 1962. lus grecoromanum, I-VIII. Aalen: Scientia. Ponatis prve izdaje, Atene 1931.

Zhishman, Joseph. 1864. Das Eherecht der orientalischen Kirche. Wien: Braumüller. 